\title{
Company's Characteristics and Accounting Information Relevance
}

\author{
Dhiaa Shamki*, Ibrahim Khalaf Alulis
}

Department of Managerial and Financial Science, Al Zahra College for Women, Sultanate of Oman

Copyright $\bigcirc 2016$ by authors, all rights reserved. Authors agree that this article remains permanently open access under the terms of the Creative Commons Attribution License 4.0 International License

\begin{abstract}
The paper examines whether company's characteristics, namely, stockholders number, listing status and company's age affect its accounting information relevance and which stock price measure, among average price, closing price and after three months price, is more dependable in pointing out the accounting information value relevance for a sample consists of 91 companies in the services and industrial sectors in Jordan within 2004-2013. Using price model, it is found that companies with larger stockholder numbers, listed on Amman Stock Exchange primary market, and that are older in age yield greater value relevance for per share earnings and book value. Book value has the greatest value relevance being the best predictor for firm value, while cash flows showed insignificant results. Finally, we concluded that closing price is the most dependable among the three stock price measures in detecting the accounting information value relevance in Jordan. The paper presents the ability of valuation theory/model to interact with other theories by including the effect of non-accounting information on the accounting information value relevance. Our findings might present evidence that can serve the educational institutions in their courses and provide a guideline to investors, managers and financial analysts to better summarize the firm value.
\end{abstract}

Keywords Value Relevance, Stockholders Number, Listing Status, Company's Age, Jordan

\section{Introduction}

A previous study found that the financial disclosure can be affected by stockholders number, listing status and company's age [5]. Few studies found that there is a significant effect of company's characteristics on firm value [6]. Therefore, to extend previous studies, we examine the effect of stockholders number, listing status and a company's age on per share earnings, book value and cash flows relevance that is not well researched particularly for Jordanian services and industrial sectors.

In the Middle Eastern region and on the contrary to developed countries, there are limited practical research on the effect of different non-accounting information on the accounting information relevance have been found in Jordan [30]. On the value relevance of accounting information, those studies examined the effect of mandated accounting disclosure, legal environment, source of accounting standards and liberalization [7], forging and local stockholders number [29], foreign ownership and trading volume [30], financial disclosure level and time [31] and industry type [32]. This study extends the valuation research in Jordan to include the effect of stockholders number, listing status and company's age on the value relevance of companies' accounting information.

Presenting the useful accounting information is what financial statements (FSs) aim to support their users to better understand and predict the firm value. As widely examined in the literature, a company's value can be summarized from the significant relationship for accounting information with stock price. Examining the effect of non-accounting variables on this relationship may extend the valuation model and provides insight to develop the valuation theory. Therefore, we try to test the effect of the company's characteristics namely stockholders number, listing status and company's age on the per share earnings, book value and cash flows relevance after putting under control both company's size and leverage for services and industrial companies within 2004-2013 in Jordan.

This examination tests the validity of the valuation theory and its ability to interact with other theories. This is done by improving the valuation model to include the effect of the non-accounting information such as stockholders number, listing status and company's age by interacting them on earnings, book value and cash flows as accounting information. Since different measurements for stock price have been used in literature and following previous valuation studies [30,31], this study examines the effect of the selected non-accounting information on the accounting 
information value relevance regarding three measures for stock price which are average price, closing price, and after three months price to indicate which stock price measure is more dependable in presenting the above accounting information relevance.

The study attempts to address two main questions of: What are the specific characteristics of a company among stockholders number, listing status and age that affect the earnings, book value and cash flows relevance? Which stock price measure among the three different measures is the most dependable to present the accounting information value relevance? Consequently, the objectives are to examine whether company's characteristics can affect the accounting information value relevance, and which stock price measure among the three different measures is the most dependable in detecting this value relevance.

The study contributes to the literature by extending valuation research to include Jordan as a developing country. Also, valuation models and analysis are extended by examining the accounting information value relevance affected by company's characteristics using three different stock price measures. Then, the expected results of this study are important to investors and other market participants for better understanding the effect of company's characteristics on the accounting information value relevance and to indicate which measure for stock price is more dependable in representing firm value. The study presents evidence that can serve as a guideline to investors, managers, and financial analysts to better evaluate the firm value. Also, this evidence can serve educational institutions in their courses.

\section{Prior Research}

\subsection{Value Relevance and Stockholders Number}

Firm financial position is considered to be stronger if the proportion of the stockholders' equity is larger [14]. Increasing firms' stockholders number could result in increasing the firms' market value and reducing the firms cost of capital, thus managers are motivated to expand the firms' stockholders number [6]. Many studies have investigated the effect of stockholders number on the disclosure level and a significant and positive effect has been concluded [5]. [29] Found a significant effect for companies' stockholders number on their earnings and book value of equity relevance in Jordanian industrial companies within 1993-2002. Starting in a new line, the current study extends these studies by testing the effect of the stockholders number on earnings, book value and cash flows relevance for both services and industrial companies in Jordan within 2004-2013 that has not been well examined before.

In accordance with [29], we expect that extending stockholders number might positively affect the accounting information value relevance. Companies with large number of stockholders like to improve their disclosure quality in order to ensure equal relevant information access for all stockholders and respond to different stockholders' needs [5]. We measure stockholders number by the total number of stockholders of a company.

\subsection{Value Relevance and Listing Status}

In Jordan, Amman Stock Exchange (ASE) has primary and secondary markets. Secondary market has been established to provide a place for companies and investors to enjoy more business opportunities out of the primary market by adopting a broader investment strategy [33]. Secondary markets' companies have lower quality due to high asymmetric information problems, lower liquidity and lower trading volume than those in the primary markets [18]. The competition among companies that are listed in primary markets is higher compared to those listed in secondary ones and thus public eyes are more focused towards them [2].

While [3] have investigated the intangible assets value relevance and [1] have investigated that of earnings and book value in primary markets' companies, the secondary markets has not been well investigated. Therefore, this study extends the above studies by testing whether listing companies on primary or secondary market can affect their earnings, book value and cash flows relevance. Since the primary markets' companies are required to disclose more relevant information to reduce FSs users uncertainty [2], we expect to find that the accounting information is more value relevant in primary markets' companies. We measure this factor by differentiating the primary and secondary markets companies.

\subsection{Value Relevance and Company's Age}

The effect of company's age on the financial disclosure has been widely tested and found to be significant because old companies have to improve their annual reports over the time [5]. As a result, reducing the asymmetric information enhances the accounting information value relevance. The effect of company's age on earnings and cash flows relevance has been tested by [9] and [4] and they found cash flows being more relevant than earnings in most firms' life cycles. Especially in Jordan, the effect of company's age on book value relevance has not been well examined before. The current study extends these studies by testing the effect of company's age on earnings, book value and cash flows relevance in Jordan.

As old companies always improve their annual reports quality over the time and at the same time young companies attempt to go public earlier, therefore they are stimulated to improve their financial reporting disclosure to more grow in future by having more financial resources [19]. Therefore, we have no clear idea whether company's age affects the value relevance of the accounting information. We measure company's age by the number of its life years. 


\subsection{Company's Size and Leverage}

Since large companies have large accounting variables then large book value and earnings, controlling company's size is essential [27]. While companies' risk level plays a moderating role regarding the factors affect the accounting information value relevance [22], it is important to control company's leverage. Following [7], [29] and [30], we measure company's size by the log of its total assets and company's leverage by its debt to total assets ratio.

\subsection{Conceptual Framework}

The relevant information is the figure that FSs users need to evaluate firm value and make a decision. Accounting information value relevance is an unclear term because different user groups for valuation purposes may have different views about what the information value relevance is [34]. [8] considered that the accounting information that investors need does not require to be new in order to be relevant, but it can be relevant by summarizing accounting information that might be taken from other sources.

Consequently, many factors might affect the relevant information and keep FSs away from fully covering the investors' needs [12]. In turn, this will affect the financial reporting quality. This is because: (1) FSs are not the only one source of information [23] which leads investors to look for relevant information from other sources; (2) the asymmetric information (agency problem) occurs because managers know more about firm affairs than investors [20; 15]; (3) economic and technology changes have affected the accounting practice [28]; (4) shifting from industrialized to high technology service economy leads FSs to lose their value relevance [24]; and (5) differences in accounting information quality occurred due to the variety in disclosure and measure practices cross-countries [21].

Accordingly, in the real world, we can't advice the accounting information users to deduce the firm value based on accounting information value relevance which is affected by those different factors. Therefore, we attempt to test the effect of different factors on the accounting information relevance to determine the validity of the valuation theory on itself and on its ability to interact with other theories (such as stockholders, capital structure and life cycle) that related to the study's selected variables.

Although managers are directed by the stockholder theory to maximize stockholders wealth, they face incentives to increase companies' stock price [11]. This may relate to the relevant accounting information that plays a real role in evaluating the firm value based on its capital structure. Interesting with capital structure theory, disclosing more relevant information, to capture more investment opportunities and enhance their profitability [5], might depend on whether a firm is listed on the primary or secondary market and its financial leverage. Valuation theory might be easily linked to life cycle theory through the efficiency of the capital market operation. Since the younger, older, smaller, or bigger firms are likely to issue new equity or have high investment opportunities relative to cash flows [16], disclosing more relevant information could increase those opportunities.

Since the developments in valuation theory allow employing different accounting and non-accounting variables in [26], the linkages among the study variables are diagramed into a framework as in Figure 1.

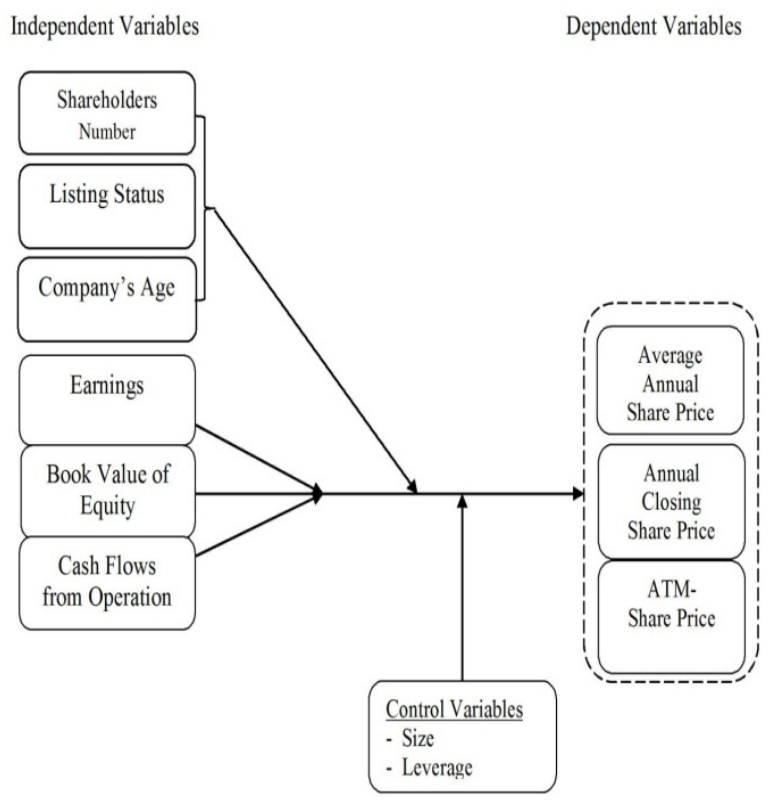

Figure 1. Conceptual Framework

\section{Hypotheses Development and Models}

Since this study aims to examine whether the earnings, book value and cash flows relevance is affected by company's stockholders number, listing status and age, the relationships among study variables are hypothesized in accordance with the three stock price measures as follows:

H1a: Earnings, book value and cash flows regarding average price are more relevant in companies with larger stockholders number.

H1b: Earnings, book value and cash flows regarding closing price are more relevant in companies with larger stockholders number.

H1c: Earnings, book value and cash flows regarding after three months price are more relevant in companies with larger stockholders number.

H2a: Earnings, book value and cash flows regarding average price are more relevant in companies listed in the primary market.

$\mathrm{H} 2 \mathrm{~b}$ : Earnings, book value and cash flows regarding closing price are more relevant in companies listed in the primary market.

H2c: Earnings, book value and cash flows regarding after three months price are more relevant in companies listed in the primary market. 
H3a: Earnings, book value and cash flows regarding average price are more relevant in companies that are older in age.

$\mathrm{H} 3 \mathrm{~b}$ : Earnings, book value and cash flows regarding closing price are more relevant in companies that are older in age.

H3c: Earnings, book value and cash flows regarding after three months price are more relevant in companies that are older in age.

Study data is extracted from the historical data of ASE companies. We selected the companies' sample to meet certain criteria of being listed in ASE with complete data regarding all our variables within study's period. Our sample is represented by 91 companies including 52 industrial companies and 39 services ones with a total of 10,010 observations related to the period from 2004 to 2013 .

For the current study, the market's reactions to earnings, book value and cash flows are reflected on the coefficients on those accounting information in the regression model and represented their value relevance. In the regression equations, we interacted the three company's characteristics with the three accounting variables to capture their moderating effect on those accounting variables relevance. Accordingly, standard multiple regressions are used to test the relationships among the three dependent variables and six independent ones after controlling companies size and leverage. We conducted our models with and without the control variables to point to their effects when they are involved in the regression equations.

To determine the effect of stockholders number, listing status and company's age on earnings, book value and cash flows value relevance, we categorize our sample regarding to whether companies have stockholders number greater than the median number in our sample, listed in primary market and older than the median age in our sample. Our models are conducted regarding the three stock price measures excluding and including the control variables as follows:

$$
\begin{aligned}
& \mathrm{P}=\mathrm{COF}_{0}+\mathrm{COF}_{1} \mathrm{CCH}_{\mathrm{SHN}, \mathrm{LST}, \mathrm{AGE}}+\mathrm{COF}_{2} \mathrm{E}+ \\
& \mathrm{COF}_{3} \mathrm{E}^{*} \mathrm{CCH}_{\mathrm{SHN}, \mathrm{LST}, \mathrm{AGE}}+\mathrm{COF}_{4} \mathrm{BV}+\mathrm{COF}_{5} \\
& \mathrm{BV}^{*} \mathrm{CCH}_{\mathrm{SHN}, \mathrm{LST}, \mathrm{AGE}}+\mathrm{COF}_{6} \mathrm{CF}+\mathrm{COF}_{7} \mathrm{CF}^{*} \\
& \mathrm{CCH}{ }_{\mathrm{SHN}, \mathrm{LST}, \mathrm{AGE}}+\varepsilon \\
& \mathrm{P}=\mathrm{COF}_{0}+\mathrm{COF}_{1} \mathrm{CCH}_{\mathrm{SHN}, \mathrm{LST}, \mathrm{AGE}}+\mathrm{COF}_{2} \mathrm{E}+ \\
& \mathrm{COF}_{3} \mathrm{E}^{*} \mathrm{CCH}_{\mathrm{SHN}, \mathrm{LST}, \mathrm{AGE}}+\mathrm{COF}_{4} \mathrm{BV}^{\mathrm{COOF}} \mathrm{COF}_{5} \\
& \mathrm{BV}^{*} \mathrm{CCH}_{\mathrm{SHN}, \mathrm{LST}, \mathrm{AGE}}+\mathrm{COF}_{6} \mathrm{CF}+\mathrm{COF}_{7} \mathrm{CF}^{*} \\
& \mathrm{CCH}_{\mathrm{SHN}, \mathrm{LST}, \mathrm{AGE}}+\mathrm{COF}_{8} \mathrm{SIZ}+\mathrm{COF}_{9} \mathrm{LVG}+\varepsilon
\end{aligned}
$$

where, for a company in a year:

$P=$ stock price referring to; average annual share price (AP), closing annual share price (CP) or after three months share price (ATMP);

$C O F=$ coefficients.

$\mathrm{CCH}_{\mathrm{SHN}}$ LST, AGE $=$ company's characteristics as a dummy variable with value 1 for;

$\mathrm{SHN}=$ stockholders number greater than median number in the sample,

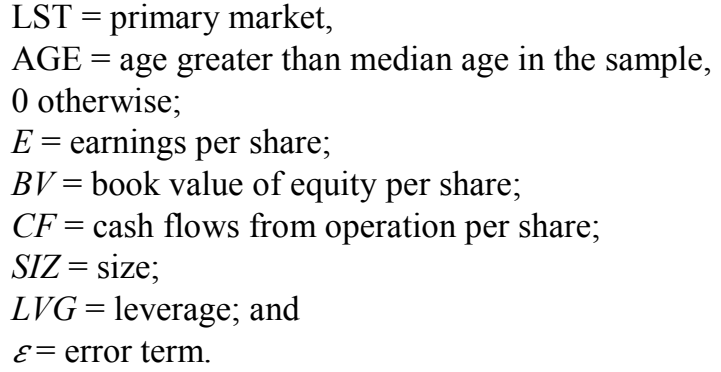

Coefficients with number 1 represent the value relevance of company's characteristics in their own rights. Coefficients numbered 2, 4 and 6 represent earnings, book value and cash flows relevance respectively without the effect of company's characteristics. Coefficients $2+3,4+5$ and $6+7$ summarize the response of stock price to earnings, book value and cash flows respectively with the effect of company's characteristics. We assume that $\mathrm{H} 1, \mathrm{H} 2$ and $\mathrm{H} 3$ as $\mathrm{H}$ : $\mathrm{COF} 3>0, \mathrm{COF} 5>0$ or $\mathrm{COF} 7>0$.

According to [10], as study models include many independent variables, Adjusted $R^{2}$ which is one of multi regression outputs assists in estimating the relation strength among our variables. To evaluate study models it needs to take in account $F$ statistical significance. Following previous studies on the value relevance [29, 30, 31], this paper depends on the statistical values of the related coefficients of the pooled sample in evaluating its hypotheses.

\section{Findings}

\subsection{Descriptive Statistics}

The descriptive statistics provide data's distribution profile to make sure that the sample is distributed normally. Using SPSS, descriptive statistics for stock price measures, accounting information, a company' characteristics and control variables are determined in Table 1.

Among the three stock price measures, average price yields the highest values for mean and median, while closing price has the lowest ones. Among the accounting variables, cash flows show the highest standard deviation while the lowest is shown by book value although all values are below 3 which ensures the absence of the outliers that might significantly influence our analysis and in turn our results. The table indicates that $68 \%$ of stockholders number and $45 \%$ of age values in the sample are larger than their median numbers in study companies' sample and $58 \%$ of the sample companies are from the primary market.

\subsection{Value Relevance and Stockholders Number}

Regarding the three stock price measures, the results reveal that stockholders number factor is relevant in its own right reflected by the significant coefficients on this factor as in Table (2). 
Table 1. Descriptive Statistics

\begin{tabular}{|c|c|c|c|c|c|c|c|}
\hline Statistics & & $A P$ & $C P$ & ATMP & $E$ & $B V$ & $C F$ \\
\hline \multirow[t]{2}{*}{$\mathrm{N}$} & Valid & 546 & 546 & 546 & 393 & 545 & 347 \\
\hline & Missing & 0 & 0 & 0 & 153 & 1 & 199 \\
\hline Mean & & .3767 & .3501 & .3667 & -.8682 & .1671 & -.7387 \\
\hline Median & & .3456 & .3201 & .3222 & -.8539 & .1271 & -.6990 \\
\hline Std. Deviation & & .33579 & .35695 & .35551 & .50245 & .22254 & .55186 \\
\hline Skewness & & .496 & .334 & .481 & -.026 & .591 & -1.138 \\
\hline Std. Error of Skewness & & .105 & .105 & .105 & .123 & .105 & .131 \\
\hline Kurtosis & & .421 & .654 & .691 & .124 & 3.131 & 5.665 \\
\hline Std. Error of Kurtosis & & .209 & .209 & .209 & .246 & .209 & .261 \\
\hline Minimum & & -.52 & -.92 & -.57 & -2.00 & -.96 & -4.40 \\
\hline Maximum & & 1.55 & 1.56 & 1.80 & .57 & 1.19 & .89 \\
\hline Statistics & & $S H N$ & $L S T$ & $A G E$ & $S I Z$ & $L V G$ & \\
\hline \multirow[t]{2}{*}{$\mathrm{N}$} & Valid & 546 & 546 & 546 & 546 & 546 & \\
\hline & Missing & 0 & 0 & 0 & 0 & 0 & \\
\hline Mean & & .68 & .58 & .45 & 7.2877 & .3030 & \\
\hline Median & & 1.00 & 1.00 & .00 & 7.2400 & .2700 & \\
\hline Std. Deviation & & .466 & .494 & .498 & .56777 & .20272 & \\
\hline Skewness & & -.789 & -.335 & .207 & .452 & .900 & \\
\hline Std. Error of Skewness & & .105 & .105 & .105 & .105 & .105 & \\
\hline Kurtosis & & -1.382 & -1.895 & -1.964 & .200 & .640 & \\
\hline Std. Error of Kurtosis & & .209 & .209 & .209 & .209 & .209 & \\
\hline Minimum & & 0 & 0 & 0 & 5.97 & .00 & \\
\hline Maximum & & 1 & 1 & 1 & 8.95 & 1.08 & \\
\hline
\end{tabular}

All variables are previously defined

Table 2. Shareholders number and accounting information relevance

\begin{tabular}{|c|c|c|c|c|c|c|}
\hline \multicolumn{7}{|c|}{$\begin{array}{c}\mathrm{P}=\delta_{0}+\delta_{1} \mathrm{SHRHNO}+\delta_{2} \mathrm{E}+\delta_{3} \mathrm{E}^{*} \mathrm{SHRHNO}+\delta_{4} \mathrm{BV}+\delta_{5} \mathrm{BV} * \mathrm{SHRHNO}+\delta_{6} \mathrm{CF}+\delta_{7} \mathrm{CF} * \mathrm{SHRHNO}+\mathrm{e} \\
\mathrm{P}=\delta_{0}+\delta_{1} \mathrm{SHRHNO}+\delta_{2} \mathrm{E}+\delta_{3} \mathrm{E} * \mathrm{SHRHNO}+\delta_{4} \mathrm{BV}+\delta_{5} \mathrm{BV} * \mathrm{SHRHNO}+\delta_{6} \mathrm{CF}+\delta_{7} \mathrm{CF} * \mathrm{SHRHNO}+\delta_{8} \mathrm{SIZ}+\delta_{9} \mathrm{LVG}+\varepsilon\end{array}$} \\
\hline P proxy & & & & & & \\
\hline Statistics & $\begin{array}{l}\text { Without } \\
\text { CVs }\end{array}$ & $\begin{array}{l}\text { With } \\
\text { CVs }\end{array}$ & Without CVs & $\begin{array}{l}\text { With } \\
\text { CVs }\end{array}$ & $\begin{array}{l}\text { Without } \\
\text { CVs }\end{array}$ & $\begin{array}{l}\text { With } \\
\text { CVs }\end{array}$ \\
\hline$\delta_{1}$ & 0.36 & 0.27 & 0.41 & 0.33 & 0.30 & 0.33 \\
\hline t-test & $3.02 * * *$ & $2.21 * *$ & $3.43 * * *$ & $2.72 * * *$ & $2.47 * *$ & $2.58 * * *$ \\
\hline$\delta_{2}$ & 0.46 & 0.41 & 0.51 & 0.48 & 0.35 & 0.29 \\
\hline t-test & $10.26 * * *$ & $9.27 * * *$ & $11.98 * * *$ & $11.09 * * *$ & $7.34 * * *$ & $6.22 * * *$ \\
\hline$\delta_{3}$ & 0.44 & 0.40 & 0.48 & 0.44 & 0.32 & 0.41 \\
\hline t-test & $4.85 * * *$ & $4.37 * * *$ & $5.24 * * *$ & $4.78 * * *$ & $3.44 * * *$ & $3.80 * * *$ \\
\hline$\delta_{4}$ & 0.58 & 0.58 & 0.58 & 0.60 & 0.55 & 0.53 \\
\hline t-test & $15.63 * * *$ & $14.94 * * *$ & $15.82 * * *$ & $15.35 * * *$ & $14.34 * * *$ & $13.36 * * *$ \\
\hline$\delta_{5}$ & 0.34 & 0.34 & 0.32 & 0.30 & 0.36 & 0.38 \\
\hline t-test & $4.51 * * *$ & $4.36 * * *$ & $4.20 * * *$ & $3.90 * * *$ & $4.57 * * *$ & $4.82 * * *$ \\
\hline$\delta_{6}$ & 0.24 & 0.24 & 0.29 & 0.30 & 0.23 & 0.24 \\
\hline t-test & $4.95 * * *$ & $5.04 * * *$ & $6.07 * * *$ & $6.32 * * *$ & $4.90 * * *$ & $5.09 * * *$ \\
\hline$\delta_{7}$ & 0.05 & 0.02 & 0.05 & 0.04 & 0.07 & 0.06 \\
\hline t-test & 0.71 & 0.31 & 0.83 & 0.57 & 1.15 & 0.92 \\
\hline$\delta_{8}$ & & 0.09 & & 0.03 & & 0.18 \\
\hline t-test & & $1.94 *$ & & 0.65 & & $3.88 * * *$ \\
\hline$\delta_{9}$ & & 0.05 & & 0.04 & & -0.002 \\
\hline t-test & & 1.11 & & 1.07 & & -0.06 \\
\hline Adj. $R^{2}$ & 0.64 & 0.65 & 0.67 & 0.67 & 0.63 & 0.65 \\
\hline $\mathrm{F}$ & $58.72 * * *$ & $45.71 * * *$ & $59.25 * * *$ & $45.72 * * *$ & $52.52 * * *$ & $41.55 * * *$ \\
\hline
\end{tabular}

Notes:

$*, * *$ and $* * *$ Significant at $10 \%, 5 \%$ and $1 \%$ levels respectively;

SHRHNO: Shareholders number;

CVs: control variables (size and leverage);

Other variables are defined before. 
However, relative to average price, closing price and after three months price with neglecting the control variables effect, the coefficients $\delta_{2}, \delta_{4}$ and $\delta_{6}$ are significant at 0.01 levels indicating that earnings, book value and cash flows are respectively relevant without the effect of stockholders number. A significant effect for stockholders number factor on earnings relevance is reflected by the significant coefficient $\delta_{3}$ at 0.01 level. This factor significantly affected the book value relevance as it is reflected by the significant coefficient $\delta_{5}$ at 0.01 level. Stockholders number factor insignificantly affected the cash flows relevance as shown by the insignificant coefficient $\delta_{7}$ for all stock price measures.

The coefficients sign for the interaction terms is found to be in congruence with Hypothesis 1. The positive coefficients $\delta_{3}, \delta_{5}$ and the insignificant $\delta_{7}$ represent that the accounting information relevance increased in a company with larger stockholders number. Stock price responds more to earnings and book value in companies with larger stockholders number as reflected by the positive coefficients on the interaction terms with those accounting variables.

In the presence of stockholders number factor, the average price, closing price, and after three months price reactions to earnings have increased from $0.46\left(\delta_{2}\right)$ to $0.90\left(\delta_{2}+\delta_{3}\right)$, 0.51 to 0.99 and from 0.35 to 0.67 respectively. The reactions of those stock price measures to book value have increased from $0.58\left(\delta_{4}\right)$ to $0.92\left(\delta_{4}+\delta_{5}\right), 0.58$ to 0.90 and from 0.55 to 0.91 respectively. The three stock price measures have no response to cash flows with the involvement of stockholders number as it is shown by the insignificant coefficients on cash flows interaction terms $\left(\delta_{7}\right)$.

\subsection{Value Relevance and Listing Status}

Regarding the three stock price measures, the study results show significant coefficients on listing status factor $\left(\phi_{1}\right)$ at 0.1 level or better which demonstrates that it is relevant in its own right as presented in Table (3).

However, regarding average price, closing price and after three months price without control variables, data analyses yield significant coefficients $\phi_{2}, \phi_{4}$ and $\phi_{6}$ at 0.01 level which demonstrates that earnings, book value and cash flows are respectively relevant without the effect of the listing status. Involving this factor produces significant effect on earnings relevance shown by the significant interaction terms coefficients where $\phi_{3}$ is significant at 0.1 level or better. This factor significantly affected the book value relevance reflected by the significant interaction terms coefficients, where $\phi_{5}$ is significant at 0.01 level. For all stock price measures, listing status factor insignificantly affected cash flows relevance reflected by the insignificant interaction terms coefficients $\left(\phi_{7}\right)$.

The sign of the interaction terms coefficients is found to be in congruence with Hypothesis 2. The positive coefficients $\phi_{3}, \phi_{5}$ indicate that the accounting information relevance is increased for companies listed in the primary market.
The three stock price measures responded more to earnings and book value for companies listed in the primary market as it is shown in Table (3) with positive coefficients on their interaction terms $\left(\phi_{3}\right.$ and $\left.\phi_{5}\right)$. In the presence of the listing status factor, the reactions of average price and closing price to earnings have increased from $0.45\left(\phi_{2}\right)$ to $0.71\left(\phi_{2}+\phi_{3}\right), 0.51$ to 0.80 and from 0.33 to 0.50 respectively, while these reactions to book value have increased from $0.57\left(\phi_{4}\right)$ to $0.89\left(\phi_{4}+\phi_{5}\right), 0.58$ to 0.87 and from 0.54 to 0.87 respectively. With the involvement of listing status factor, there is no response for the three stock price measures to cash flows as represented by the insignificant coefficients on their interaction terms $\left(\phi_{7}\right)$.

\subsection{Value Relevance and Company's Age}

Regarding the three stock price measures, significant coefficients at 0.05 level or better for company's age $\left(\lambda_{1}\right)$ has been found which indicates the relevance of company's age factor in its own right as presented in Table (4).

However, for average price, closing price and after three months price without control variables, the results show significant coefficients $\lambda_{2}, \lambda_{4}$ and $\lambda_{6}$ at 0.01 level which indicates that earnings, book value and cash flows are respectively relevant without the effect of company's age. Involving this factor has significantly affected the earnings relevance as it is reflected by the significant coefficients on their interaction terms at 0.05 level or better. Thus, this factor significantly has affected the book value relevance as it is reflected by the significant coefficients on their interaction terms at 0.01 level. Regressing on closing price and after three months price, company's age insignificantly has affected the cash flows relevance reflected by the insignificance of the interaction terms coefficients, while regressing on average price shows significant effect at 0.1 level.

The coefficients sign of the interaction terms is found to be consistent with Hypothesis 3 . The positive coefficients $\lambda_{3}, \lambda_{5}$ (and $\lambda_{7}$ although it is insignificant except with average price) which indicate that the accounting information relevance has increased for companies that are older in their age. For those companies, stock price have measures responded more for earnings and book value as it is illustrated by the positive coefficients on these accounting variables interaction terms $\left(\lambda_{3}\right.$ and $\left.\lambda_{5}\right)$. Involving company's age factor, average price, closing price, and after three months price reactions to earnings have increased from $0.46\left(\lambda_{2}\right)$ to $0.75\left(\lambda_{2}+\lambda_{3}\right), 0.51$ to 0.88 and from 0.35 to 0.58 respectively. These reactions to book value have increased from $0.58\left(\lambda_{4}\right)$ to $0.88\left(\lambda_{4}+\lambda_{5}\right)$, 0.58 to 0.84 and from 0.55 to 0.89 respectively. However, by including the effect of this factor, no response for closing price and after three months price measures has been found for cash flows as it is shown by the insignificance of the interaction terms coefficients on cash flows $\left(\lambda_{7}\right)$, while a weak significant response is shown by average price $\left(\lambda_{6+} \lambda_{7}=\right.$ $0.34)$. 
Table 3. Listing status and accounting information relevance

\begin{tabular}{|c|c|c|c|c|c|c|}
\hline \multirow{3}{*}{$\frac{\mathrm{P}=}{\mathrm{xy}}$} & \multicolumn{6}{|c|}{$\begin{array}{l}=\phi_{0}+\phi_{1} \text { LSTUS }+\phi_{2} \mathrm{E}+\phi_{3} \mathrm{E}^{*} \mathrm{LSTUS}+\phi_{4} \mathrm{BV}+\phi_{5} \mathrm{BV}^{*} \mathrm{LSTUS}+\phi_{6} \mathrm{CF}+\phi_{7} \mathrm{CF}^{*} \mathrm{LSTUS}+\mathrm{e} \\
\phi_{1} \mathrm{LSTUS}+\phi_{2} \mathrm{E}+\phi_{3} \mathrm{E}^{*} \mathrm{LSTUS}+\phi_{4} \mathrm{BV}+\phi_{5} \mathrm{BV}^{*} \mathrm{LSTUS}+\phi_{6} \mathrm{CF}+\phi_{7} \mathrm{CF}^{*} \mathrm{LSTUS}+\phi_{8} \mathrm{SIZ}+\phi_{9} \mathrm{LVG}+\varepsilon\end{array}$} \\
\hline & \multicolumn{2}{|c|}{$\mathrm{AP}$} & \multicolumn{2}{|c|}{$\mathrm{CP}$} & \multicolumn{2}{|c|}{ ATMP } \\
\hline & $\begin{array}{l}\text { Without } \\
\text { CVs }\end{array}$ & $\begin{array}{l}\text { With } \\
\text { CVs }\end{array}$ & Without CVs & $\begin{array}{l}\text { With } \\
\text { CVs }\end{array}$ & Without CVs & $\begin{array}{l}\text { With } \\
\text { CVs }\end{array}$ \\
\hline$\phi 1$ & 0.25 & 0.22 & 0.34 & 0.31 & 0.20 & 0.15 \\
\hline t-test & $2.15 * *$ & $1.84 *$ & $2.87 * * *$ & $2.60 * * *$ & $1.68 *$ & 1.23 \\
\hline t-test & $9.86 * * *$ & $9.04 * * *$ & $11.62 * * *$ & $10.87 * * *$ & $6.84 * * *$ & $5.90 * * *$ \\
\hline$\phi 3$ & 0.26 & 0.24 & 0.29 & 0.27 & 0.17 & 0.14 \\
\hline t-test & $3.03 * * *$ & $2.82 * * *$ & $3.32 * * *$ & $3.12 * * *$ & $1.95 *$ & $1.66^{*}$ \\
\hline$\phi 4$ & 0.57 & 0.57 & 0.58 & 0.59 & 0.54 & 0.53 \\
\hline t-test & $15.42 * * *$ & $14.80 * * *$ & $15.65 * * *$ & $15.21 * * *$ & $14.18 * * *$ & $13.28 * * *$ \\
\hline$\phi 5$ & 0.32 & 0.28 & 0.29 & 0.25 & 0.33 & 0.28 \\
\hline $\mathrm{t}$-test & $4.53 * * *$ & $3.95 * * *$ & $4.05 * * *$ & $3.44 * * *$ & $4.46 * * *$ & $3.84 * * *$ \\
\hline t-test & $5.20 * * *$ & $5.21 * * *$ & $6.27 * * *$ & $6.44 * * *$ & $5.14 * * *$ & $5.25 * * *$ \\
\hline$\phi 7$ & -0.05 & -0.05 & -0.01 & -0.01 & -0.01 & -0.02 \\
\hline t-test & -0.77 & -0.77 & -0.12 & -0.10 & -0.15 & -0.25 \\
\hline$\phi 8$ & & 0.09 & & 0.05 & & 0.17 \\
\hline t-test & & $2.02 * *$ & & 1.07 & & $3.97 * * *$ \\
\hline$\phi 9$ & & 0.05 & & 0.04 & & 0.000 \\
\hline t-test & & 1.16 & & 0.97 & & 0.000 \\
\hline Adj. $\mathrm{R}^{2}$ & 0.64 & 0.65 & 0.66 & 0.67 & 0.63 & 0.65 \\
\hline $\mathrm{F}$ & $54.89 * * *$ & $44.53 * * *$ & $53.40 * * *$ & $43.41 * * *$ & $50.32 * * *$ & $43.43 * * *$ \\
\hline
\end{tabular}

Notes:

$*, * *$ and $* * *$ Significant at $10 \%, 5 \%$ and $1 \%$ levels respectively;

LSTUS: Listing status;

Other variables are defined before.

Table 4. Company's age and accounting information relevance

\begin{tabular}{|c|c|c|c|c|c|c|}
\hline \multicolumn{7}{|c|}{$\begin{array}{c}\mathrm{P}=\lambda_{0}+\lambda_{1} \mathrm{AGE}+\lambda_{2} \mathrm{E}+\lambda_{3} \mathrm{E}^{*} \mathrm{AGE}+\lambda_{4} \mathrm{BV}+\lambda_{5} \mathrm{BV}^{*} \mathrm{AGE}+\lambda_{6} \mathrm{CF}+\lambda_{7} \mathrm{CF}^{*} \mathrm{AGE}+\mathrm{e} \\
\mathrm{P}=\lambda_{0}+\lambda_{1} \mathrm{AGE}+\lambda_{2} \mathrm{E}+\lambda_{3} \mathrm{E}^{*} \mathrm{AGE}+\lambda_{4} \mathrm{BV}+\lambda_{5} \mathrm{BV}^{*} \mathrm{AGE}+\lambda_{6} \mathrm{CF}+\lambda_{7} \mathrm{CF}^{*} \mathrm{AGE}+\lambda_{8} \mathrm{SIZ}+\lambda_{9} \mathrm{LVG}+\varepsilon\end{array}$} \\
\hline P proxy & \multicolumn{2}{|c|}{ AP } & \multicolumn{2}{|c|}{$\mathrm{CP}$} & \multicolumn{2}{|c|}{ ATMP } \\
\hline Statisti & Without CVs & $\begin{array}{l}\text { With } \\
\text { CVs }\end{array}$ & $\begin{array}{l}\text { Without } \\
\text { CVs }\end{array}$ & $\begin{array}{l}\text { With } \\
\text { CVs }\end{array}$ & Without CVs & $\begin{array}{l}\text { With } \\
\text { CVs }\end{array}$ \\
\hline$\lambda_{1}$ & 0.46 & 0.45 & 0.60 & 0.59 & 0.32 & 0.29 \\
\hline t-test & $3.80 * * *$ & $3.74 * * *$ & $5.05 * * *$ & $5.01 * * *$ & $2.57 * *$ & $2.41 * *$ \\
\hline$\lambda_{2}$ & 0.46 & 0.41 & 0.51 & 0.47 & 0.35 & 0.29 \\
\hline t-test & $10.25 * * *$ & $9.23 * * *$ & $11.97 * * *$ & $11.03 * * *$ & $7.31 * * *$ & $6.16 * * *$ \\
\hline$\lambda_{3}$ & 0.29 & 0.28 & 0.37 & 0.36 & 0.23 & 0.22 \\
\hline t-test & $3.34 * * *$ & $3.26 * * *$ & $4.28 * * *$ & $4.21 * * *$ & $2.63 * * *$ & $2.53 * *$ \\
\hline$\lambda_{4}$ & 0.58 & 0.58 & 0.58 & 0.59 & 0.55 & 0.53 \\
\hline t-test & $15.61 * * *$ & $14.90 * * *$ & $15.80 * * *$ & $15.29 * * *$ & $14.30 * * *$ & $13.33 * * *$ \\
\hline$\lambda_{5}$ & 0.30 & 0.26 & 0.26 & 0.22 & 0.34 & 0.29 \\
\hline t-test & $3.87 * * *$ & $3.26 * * *$ & $3.32 * * *$ & $2.80 * * *$ & $4.33 * * *$ & $3.68 * * *$ \\
\hline t-test & $4.92 * * *$ & $5.00 * * *$ & $6.03 * * *$ & $6.20 * * *$ & $4.86 * * *$ & $5.04 * * *$ \\
\hline$\lambda_{7}$ & 0.10 & 0.07 & 0.09 & 0.07 & 0.06 & 0.01 \\
\hline t-test & $1.74 *$ & 1.19 & 1.61 & 1.22 & 1.08 & 0.22 \\
\hline$\lambda_{8}$ & & 0.09 & & 0.04 & & 0.17 \\
\hline t-test & & $1.91 *$ & & 0.97 & & $3.82 * * *$ \\
\hline$\lambda_{9}$ & & 0.04 & & 0.04 & & -0.003 \\
\hline t-test & & 0.99 & & 0.90 & & -0.08 \\
\hline Adj. $\mathrm{R}^{2}$ & 0.65 & 0.65 & 0.67 & 0.70 & 0.63 & 0.65 \\
\hline $\mathrm{F}$ & $65.12 * * *$ & $53.00 * * *$ & $70.61 * * *$ & $55.38 * * *$ & $61.67 * * *$ & $53.78 * * *$ \\
\hline
\end{tabular}

Notes:

$*, * *$ and $* * *$ Significant at $10 \%, 5 \%$ and $1 \%$ levels respectively;

$A G E$ : Company's age;

Other variables are defined before. 
Tables 2, 3 and 4 show that including companies size and leverage in our models produces stronger adjusted $R^{2}$ while the interaction terms importance and significance keep their trend except that for cash flows which became insignificant with the effect of company's age. The increase in the values of adjusted $R^{2}$ is largely ascribable to the effect of the control variables. The significance of $F$ statistic ensures that study models as a whole are significant.

\section{Discussion and Conclusion}

\subsection{Value Relevance and Stockholders Number}

The increase in the earnings and book value relevance for companies with larger stockholders number which is hypothesized in $\mathrm{H} 1$ is expected. This might be explained by that the extent in stockholders number is positively related to stock price [6] and in turn increases the accounting information relevance.

The stockholders theory could explain the positive and significant effect of stockholders number on the earnings and book value relevance by that companies aim to increase their stockholders interest, which can be done by increasing their stocks value and in turn their firm value. Since stockholders controlling can directly or indirectly affect the managers' decisions [5], managers have to follow the stockholders' demands by disclosing relevant information. Stockholders theory directed managers to increase companies' stock price. A company's stock price might diverge from its intrinsic value due to instantaneously and continuously information communicated to the markets [11]. The effect of stockholders number factor on the earnings and book value relevance is consistent with that concluded by [29].

Study results revealed that stockholders number insignificantly affected the cash flows relevance regarding the three stock price measures. This unexpected result might be explained by that cash flows are not directly paid out as dividends and managers are allowed by stockholders to retain cash which might be misused in unprofitable or negative projects $[20,36]$. Since no previous studies on the effect of stockholders number on cash flows relevance have been found, the study results cannot be evidenced with other studies. Consequently $\mathrm{H} 1 \mathrm{a}, \mathrm{H} 1 \mathrm{~b}$ and $\mathrm{H} 1 \mathrm{c}$ are adopted for earnings and book value but not for cash flows.

\subsection{Value Relevance and Listing Status}

The increase in earnings and book value relevance for companies listed in the primary market which hypothesized in $\mathrm{H} 2$ is expected. This might be explained by that primary markets' companies (1) have to decrease the asymmetric information, which is considered as the major factor affecting the accounting information value relevance, by disclosing more relevant information, (2) are able to increase their stockholders number which has positive effect on stock price appreciation [6], and (3) competition is higher among these companies than that of secondary market $[2,18]$. This result is consistent with the study of [1].

Theoretically, stock market is of benefit to market participants if it is informationally efficient. This benefit includes the wealth allocation among companies that can be determined by stock prices, which are affected by the financial information [23]. Study result regarding Hypothesis 2 might be explained by that companies' capital structure reflects their growth opportunities which affected the firm value. These opportunities are higher in primary markets' companies which try to capture more investments and enhance their profitability by disclosing more relevant information than that in secondary markets $[2,5]$.

Study results indicated that listing status insignificantly affected cash flows relevance regarding the three stock price measures. This unexpected result might be due to that Jordanian investors are concerned about how to gain quickly, and they have lack the awareness or understanding the relevant information available in FSs [25]. Since no previous studies on the effect of listing status on the cash flows relevance have been found, the results cannot be compared. Consequently, $\mathrm{H} 2 \mathrm{a}, \mathrm{H} 2 \mathrm{~b}$ and $\mathrm{H} 2 \mathrm{c}$ are adopted for earnings and book value but not for cash flows.

\subsection{Value Relevance and Company's Age}

It is expected that earnings and book value relevance is increased for companies that are older in age as it is hypothesized in H3. Study result regarding earnings is consistent with previous studies $[9,4]$. According to firm life cycle theory which is related to the capital market operation efficiency, this result might be explained by that older companies re-invest too large percentage of their internal funds, while young companies invest at roughly the levels that maximize present values [16].

Study results also have indicated that company's age insignificantly affected the cash flows relevance regarding the average price and after three months price measures, while a marginal significant effect has been concluded for closing price. This insignificant result might be explained by that cash flows are not a needful number for accounting principles to rely on, and it cannot limit the successfulness of a company's performance $[13,35]$. This unexpected result for cash flows is inconsistent with that from previous studies $[9,4]$. This might be explained by that Jordanian investors focus more on earnings than cash flows [17] or it might be related to the research sample or period.

According to the researchers' knowledge, no studies on the effect of company's age on the book value relevance have been found. Therefore, study results cannot be compared. Consequently, $\mathrm{H} 3 \mathrm{a}, \mathrm{H} 3 \mathrm{~b}$ and $\mathrm{H} 3 \mathrm{c}$ are adopted for earnings and book value but not for cash flows.

Regarding our results in previous sections and relative to the coefficients significance and models' adjusted $R^{2}$, closing price measure is considered to be more dependable in detecting the value relevance of the accounting information 
in Jordan since it shows the best results among the three share price measures

\section{Contributions and Future Studies}

Since there is a significant effect for company's characteristics on book value and earnings relevance, study results can assist FSs users for better understanding the firm value by linking companies' accounting information value relevance with their characteristics. One important contribution for current study is to enrich the theory of valuation by involving the effect of non-accounting information regarding different theories on the accounting information value relevance.

Current study's outcomes are relevant for the accounting courses, which are involved in analyzing FSs and the theory and practice for accounting valuation. Therefore, taking into consideration the effect of different company's characteristics on the accounting information value relevance could be of interest in FSs analysis and valuation. Study models can be used to indicate firm value depending on the accounting information that is affected by its characteristics and reliability of stock price measure. This could be useful to assess the FSs' completeness.

As the small size and observations represent important limitations, we depended on the pooled data in evaluating our results. Future studies are invited to extend this study by measuring the effect of other company's characteristics on the accounting information relevance. This might present new evidence regarding the possible companies' characteristics that could affect the accounting information relevance. Researchers, who are interested in area of research, are encouraged to expand the research period and sample size to determine their effects on the accounting information relevance. Finally they are called to investigate the accounting information relevance across countries in Middle Eastern region or across the world to validate the comparison between their expected results to generalize this study results.

\section{REFERENCES}

[1] Aba Ibrahim, M., Bujang, H., Madi, N., Abu Samah, A., Ismai, U., Jusoff, K. and Azlina, N. (2009), "Value-relevance of accounting numbers for valuation", Journal of Modern Accounting and Auditing, Vol. 5 No. 9, pp. 30-39.

[2] Abdul Samad, F. (2002), "Ownership structure in the Malaysian corporation sector: Its impact on corporate governance, performance, financing and investment patterns", Working paper, Institute for development policy and management, University of Manchester, October.

[3] Abdul-Shukor, Z., Ibrahim, M. K., Kaur, J. and Md-Nor, H. (2008), "The value relevance of intangibles non-current assets in different economic conditions", International
Review of Business Research Papers, Vol. 4 No 2, pp. 316-337.

[4] Aharony, J., Falk, H. and Yehuda, N. (2006), "Corporate life cycle and the relative value relevance of cash flow versus accrual financial information" Working paper, Faculty of Industrial Engineering and Management, 3 July.

[5] Al Arussi, A., Hisyam, M. and Hanefah M. (2009), "Determinants of financial and environmental disclosures through the internet by Malaysian companies", Asian Review of Accounting, Vol. 17 No. 1, pp. 59-76.

[6] Amihud, Y., Mendelson, H. and Uno, J. (1999), "Number of stockholders and stock prices: Evidence from Japan", The Journal of Finance, Vol. 54 No. 3, pp. 1169-1184.

[7] Anandarajan, A. and Hasan, I. (2010), "Value relevance of earnings: Evidence from Middle Eastern and North African countries", Advances in Accounting, Incorporating Advances in International Accounting, Vol. 26 No. 2, pp. 270-279.

[8] Bao, Y. (2004), "The accounting information value relevance: evidence from Asian markets”, Ph.D. thesis, Graduate School of Manangement, Kent State University.

[9] Black, E. L. (1998), "Which is more value relevant: Earnings or cash flows? A life cycle examination", Journal of Financial Statements Analysis, Vol. 4 No. 40, pp. 40-56.

[10] Cavana, R. Y., Delahaye, B. L. and Sekaran, U. (2001). Applied business research: Qualitative and quantitative methods. John Wiley and Sons, Inc.

[11] Danielson, M. G., Heck, J. L. and Shaffer, D. R. (2008), "Stockholder theory: How opponents and proponents both get it wrong", Journal of Applied Finance, Vol. 18 No. 2, pp. 62-66.

[12] Financial Accounting Standards Board (FASB). (1978), "Statement of Financial Accounting Concepts No. 1, Objectives of Financial Reporting by Business Enterprises" available at: http://www.fasb.org (accessed 11 August 2015).

[13] Financial Accounting Standards Board (FASB). (1987), "Statement of Financial Accounting Concepts No. 95, Statement of Cash Flows", available at: http://www.fasb.org (accessed 11 August 2015).

[14] Glautier, M. and Underdown, B. (1997), “Accounting theory and practice", $6^{\text {th }}$ ed, William Clowes.

[15] Godfrey, J., Hodgson, A. and Holmes, S. (2003), “Accounting theory", $5^{\text {th }}$ ed, Milton, Wiley.

[16] Grabowski, H. G. and Mueller, D. C. (1975), "Life-cycle effects on corporate returns on retentions", The Review of Economics and Statistics, Vol. 57 No. 4, pp. 400-409.

[17] Hadi, M. (2005), "Information content of cash flows data: Evidence for Jordon", Working paper, Kuwait University, Kuwait.

[18] How, J., Jelic, R., Saadouni, B. and Verhoeven, P. (2007), "Stock allocations and performance of KLSE second board IPOs", Pacific-Basin Finance Journal, Vol. 15, pp. 292-314.

[19] Huynh, K. P. and Petrunia, R. J. (2010), "Age effects, leverage and firm growth", Journal of Economic Dynamics and Control, Vol. 34, pp. 1003-1013.

[20] Jensen, M. and Meckling, W. (1976), "Theory of the firm: 
Managerial behavior, agency costs and ownership structure", Journal of Financial Economics, Vol.3, pp. 305-360.

[21] Joos, P. and Lang, M. (1994), "The effects of accounting diversity: Evidence from the European Union", Journal of Accounting Research, Vol. 32, pp. 141- 168.

[22] Kothari, S. P. (2000), "The role of financial reporting in reducing financial risks in the market", Federal Reserve Bank of Boston, Conference Series No. 44, pp. 89-102

[23] Kothari, S.P. (2001), "Capital markets research in accounting", Journal of Accounting and Economics, Vol. 31, pp. 105-231.

[24] Lev, B. and Zarowin, P. (1999), "The boundaries of financial reporting and how to extend them" Journal of Accounting Research, Vol. 37, pp. 353-385.

[25] Obaidat, A. N. (2007), "Accounting information qualitative characteristics gap: Evidence from Jordan" International Management Review, Vol. 3 No. (2), pp. 26-32.

[26] Ohlson, J. (1995), "Earnings, book values, and dividends in equity valuation" Contemporary Accounting Research, Vol. 11 No. 2, pp. 661-687.

[27] Ota, K. (2001), "The value-relevance of book value, current earnings, and management forecasts of earnings". Working paper, Musashi University, 19 August.

[28] Oyerinde, D. T. (2009), "Accounting information value relevance in emerging stock market: The case of Nigeria", Proceedings of the $10^{\text {th }}$ Annual Conference C2009 IAABD, Repositioning African Business and Development for the $21^{\text {st }}$ Century Simon Sigué (Ed.), 9-14.

[29] Shamki, D. (2012), "Impact of non-accounting information on the accounting information value relevance: The case of Jordan", International Journal of Business and Social Research, Vol. 1 No. 2, pp. 9-24.

[30] Shamki, D. (2013), "The Influence of economic factors on the accounting information value relevance in Jordan", International Journal of Business and management, Vol. 8, No 6, pp. 89-104.

[31] Shamki, D. and Abdul Rahman, A. (2013), "Does financial disclosure influence the accounting information value relevance?", Education, Business and Society: Contemporary Middle Eastern Issues, Vol. 6 No. 3/4, pp. 216-232.

[32] Shamki, D. and Bamahros, H. M. (2016). Industry Type and Accounting Numbers Relevance: The Case of Jordan. Asian Journal of Social Sciences and Management Studies, 3(3): pp 191-197.

[33] Sori, Z. M. and Mohamad, S. (2008), "Governance structure and external audit price: Evidence from an emerging economy", International Journal of Economics and Management, Vol. 2 No. 2, pp. 259-279.

[34] Thinggaard, F. and Damkier, J. (2008), "Has financial statement information become less relevant? Longitudinal evidence from Denmark", Scandinavian Journal of Management, Vol. 24 No. 4, pp. 375-387.

[35] Vélez-Pareja, I. (2005). Once more, the correct definition for the cash flows to value firm (free cash flow and cash flow to equity). Working paper. Universidad Tecnologica de Bolivar.

[36] Zeitun, R., Tian, G. and Keen, S. (2007), "Default probability for the Jordanian companies: A test of cash flow theory", International Research Journal of Finance and Economics, Vol. 8, pp. 147-162. 